\title{
TACTILE MAPS BASED ON 3D PRINTING TECHNOLOGY
}

\author{
Vít Voženílek \\ Alena Vondráková \\ Palacky University Olomouc, Czech Republic
}

\begin{abstract}
The authors present the research seeking evaluating and developing aspects of interpretation and perception of geospace by modern tactile maps based on $3 D$ printing. There are three newly introduced types of tactile maps. Map of type A is a tactile map printed by $3 D$ printing technology as traditional relief tactile map with $5 \mathrm{~mm}$ thick background using both positive and negative relief with labelling by Braille letters. Map of type $B$ is an inverse form of tactile map printed by $3 D$ printing technology which will be used for casting type $A$ tactile maps. Finally map of type $C$ is a sound tactile map derived from map of type A posed onto box with digital voice records of geoinformation (attributes, navigations etc.) activated by touch on maps surface. The paper also describes present situation in tactile maps production and steps in recent testing the new type maps.
\end{abstract}

Keywords: atlas, disability; map; spatial distribution. special education; vision impaired people

\section{Introduction}

Present modern information-based society offers many possibilities for visualisation of geospace using the latest information technologies (Voženílek, 2009). Geospace (geographic space) is defined as a part of landscape environment determined by places of human activities influence on the nature. Geospace (determined by that way) is perceived by human being through its senses or vicariously by geoinformation (geographic information, spatially located information) (Voženílek, 2002; Svobodová \& Voženílek, 2010). Correct geospace perception is precondition for both practical life at any place on the Earth and for cognitive process of natural and social phenomena (objects and processes) (Popelka\& Voženílek, 2012; Popelka, Brychtová\& Voženílek, 2012). Integration of blind people into ordinary life in geospace is very difficult process. The research topics related to geospace presentation by blind people are deal with in Anglo-Saxon countries from 80s of the $20^{\text {th }}$ century (Brychtová, Popelka\& Voženílek, 2012).

The first tactile maps served for practicing of spatial orientation and movement and they used lineal representation of everyday pathways for various users (i.e. way from home to office, shipping etc.) by form of pressed plastic plate made at special vacuum printers. These types of tactile maps are used more as technical aids rather than geospace representations. The only approximation of real geospace was so called 3D maps - plastic embossment maps primary designed seeing people and intermediating the blind perception of earth surface complexity. However they cannot provide him geographical information (occurrence point, linear ad aerial phenomena - i.e. hospital, railways, protected areas etc.). During 1990s quality and technology of printers was improved and it impacted tactile maps production. 
Many teachers of blind people have only two possibilities for teaching geospace perception - pressed plates and plastic relief maps (thermo-vacuum plates, thermoactive foam materials, individual handy-made maps). The teachers help themselves by various modifications of plastic maps - i.e. emphasizing linear symbols by fabric or plastic belts or by labels with Braille letters. According to data of Tyfloserviso.p.s. (department of Association of the blind in the Czech Republic) training of spatial orientation and movement in courses is $22 \%$, special graphics $2 \%$, Braille learning $8 \%$ and using technical aids $8 \%$. Tactile maps would be more practical and effective in all trainings and contribute to better client adaptation (Jesenský, 1970). Tactile maps availability and their high costs are the greatest barriers in many countries for their better development, distribution and using (Voženílek, Kudělka, Horák\&Snášel, 2012).

\section{The aims of the research}

The main aim of the authors' research is to assess and to develop all aspects of interpretation and perception of geospace by spatial information on modern type tactile maps based on 3D printing from the view of current state of cartographical production technology. The research consists of particulars topics as assessment of world methodologies and standards for tactile maps production, user's requirements analysis on present tactile maps and analysis of 3D printing technology for tactile maps production in GIS (Tuček, Pászto\& Voženílek, 2009). The main part of research includes designing and completing geodatabase tactile maps production, compiling of tactile maps symbology within GIS and printing new three types of tactile maps by 3D printing technology (Horák, Kudělka, Snášel\& Voženílek, 2011). The research will conclude by testing printed tactile maps by end users (the blind).

Tactile maps of modern type means three map modifications (all coloured):

Type A: tactile map printed by 3D printing technology (Contex 3D printers) as traditional relief tactile map with $5 \mathrm{~mm}$ thick base using both positive and negative relief with labelling by Braille,

Type B:inverse form of tactile map printed by 3D printing technology which will be used for casting type A tactile maps,

Type C:sound tactile map (of type A) posed onto a box with digital voice geoinformation activated by touch on maps surface.

The particular task of design, development and usability of maps for persons with visual impairment is based on the actual needs of these persons (Ungar, Jehoel, Mccallum\& Rowell, 2005). The general principles of development of maps for persons with visual impairment are crucial when preparing such maps (Vondráková, Vávra \& Voženílek, 2013; Burian, Brus \& Voženílek, 2013). The principles are: the overall slipperiness of the material surface, the factors concerning the health risks of the material used, the suitability of the material for touching, the possibility to wash the material which is connected with hygiene conditions of its usage and the necessity to carry out a survey of usefulness and 
purposefulness of the map which is actually being prepared (Dvorský, Snášel \& Voženílek, 2009). The map have to be as concise as possible and it depicts only necessities, but it should at the same time give the person overall information about the place. During the research the authors cooperated with the organisation Tyflocentrum Olomouc and the actual users of the tactile maps to determine the most suitable and acceptable technical parameters (such as descriptions, colours, abbreviations, sign keys etc.) from those stated in various publications and resources. However, the complete research concerning maps and plans for persons with visual impairment that are already being used was not carried out in the Czech Republic yet. As a consequence we have to prepare the databases of more complete maps and plans first and only after that we will select the most suitable technical parameters which we will consult with specialists (teachers and advisers) before final decisions.

After preliminary analysis of used tactile map printing technologies the authors can comment that new 3D printing technology based on layering and gluing gips powder makes possible new capabilities in 3D object modelling. Tactile maps are only one of possible ways of applying that technology. Used 3D printing was by maximal format $254 \times 356 \times 203 \mathrm{~mm}$ and thickness of one layer $0.089-0.203$ $\mathrm{mm}$. However progress in improving technical parameters of other printing technologies is so rapid that at the end of research activities the parameters of 3D printing will be twice stronger (Voženílek, 2002). Nevertheless current parameters are sufficient for required criteria of tactile models (it means maximal width $55 \mathrm{~cm}$, length for bimanual perception $105 \mathrm{~cm}$, for monomanual 75-80 cm) (Lamotte\& Whitehouse, 1986). ESRI products are selected as the fundamental software environment for the research implementation (Dvorský, Snášel\& Voženílek, 2010). All basic relief expression parameters of tactile models will be, especially relief point radius $1.2 \mathrm{~mm}$, point height $0.75 \mathrm{~mm}$, spacing in base $1.2 \mathrm{~mm}$, spacing in top $2.4 \mathrm{~mm}$, parabolic shape of relief line (height:width $\sim 3: 2$ ), distance lines and points etc. (Theissen, 2000). The authors set methodology for tactile map computer model building (from easily available data sets) and conversion approach into output (3D printer) device language.

Within research, 3D printing (at Contex printer) tactile map of type A has been produced. Because printed model consists of $50 \%$ of pores it was easy to apply infiltrants arranging selected properties. Contex Company provides many preparations which can make the model either hard, flexile, smooth, waterproof etc. This is used when looking for the best printing procedures. The printed maps were used for testing by end blind users (see below). The printing procedure respected all rules for tactile model constructing, i.e. surface roughness, health wholesomeness, touch amenity, washing and other hygienic requirements. Particular manuals for the first tactile map type is compiling now (Hirn, 2005). The first point of view is the one of blind and purblind pupils of the Czech elementary and secondary schools- those whose impairment is inborn (congenital visual impairment). The second one is the one of adult users of 
maps - the clients of organisations typhlo-centres and typhlo-services from the whole Czech Republic. These users will be divided into two groups of blind adults - first, adults with congenital blindness (they try to improve their abilities and skills) and second, the persons who became blind during their life (they have to develop necessary abilities and learn how to use them).

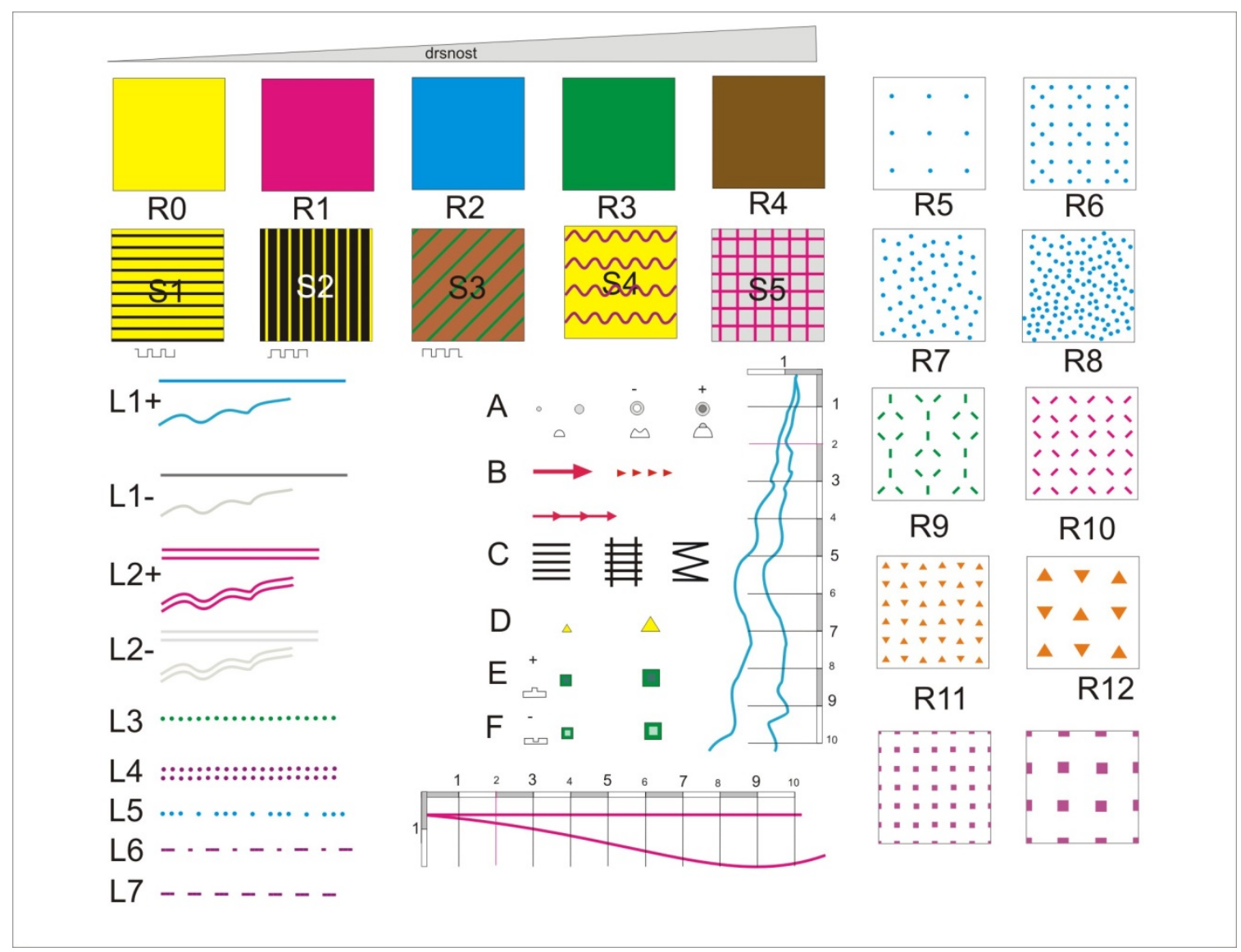

Figure 1 Testing board for tactile map of type A producing Explanations: $R 0-R 4$ roughness/harshness; $R$ 5-R12 testing types of patterns; L1-L7 testing lines with positive and negative embossing; $A$ - point marker - circular with positive and negative embossing; $B$ direction marker, arrows; $C$-impediment marker - stairs, rails, zebra crossing; $D-F$ point markers - triangle, square - with positive and negative embossing; no marking - testing measures for recognition of double or single embossed line-curved lines (blue) and straight lines (red)

The testing by adult users of both groups (congenital and acquired blindness) will be carried out in cooperation with organisation Tyflocentrum Olomouc, which successfully cooperates with the department of special education on a long time basis and which has already agreed on the cooperation. Tyflocentrum Olomouc as well as the research applicants supposes that, thanks to the outcomes of testing of individual groups, they will be able to identify plans and maps suitable for each degree of visual loss, proper colour contrast and marks and abbreviations appropriate for tactile as well as visual perception. 


\section{Testing of tactile maps of Type A}

Modern tactile maps are stipulated mainly for blind persons and persons with severe visual debility. They should help pupils and students and primary and secondary schools, as well as adults, as part of spatial orientation and independent movement training. The authors have therefore, for the purpose of testing, contacted educational organizations for pupils and students, and at the same time institutions, which provide services to adults - i.e. typhlo-service and typhlo-centre (organizations for adults with visual impairment, dealing with 2 . degree physiotherapy). The following institutions, out of those researchers have contacted, promised to cooperate:

- 3 primary schools for pupils with visual impairment,

- 2 secondary schools (Grammar school and Secondary Vocational school),

- 2 typhlo-centres.

When selecting a sample stipulated for testing, the authors tried to accept the variations in approaches to persons with various degrees of impairment in various age categories (Wiedel\& Groves, 1969; Lederman, 1974). From the perspective of blind persons, it is mainly the tactile experience which is important and which can be further used in their practical lives. On the other hand for persons with severe visual debility, focus on tactile as well as coloured and contrasting design of samples, legends and thus created tactile maps, is desirable.

In relation to individual age groups, it is always essential to take into consideration the experiences that the respondents have gained, and it was always important to take it into account within the testing perimeters (Gilbert, 1988). The expected variations between children and students of primary and secondary schools with clear visual deficiencies, and persons with a combined impairment (out of which one is a visual impairment) were often confirmed within the scope of testing, and this factor will have to be considered in the subsequent phase of further maps creation and follow-up testing (Rowell \&Ungar, 2005).

The tests were carried out at selected institutions, at the end of 2008. Our cooperation with these establishments was excellent to the point that our expectations were exceeded, and the test participants expressed great interest not only in the presented samples, but also in further development and the possibility of a future offer of modern type tactile maps. Not only the educational and counselling approached institutions, but also institutions, whose scope of activities does not involve care and services for persons with visual impairment, expressed interest in maps that the authors presented and proposed in certain alternatives (Edman, 1992). 


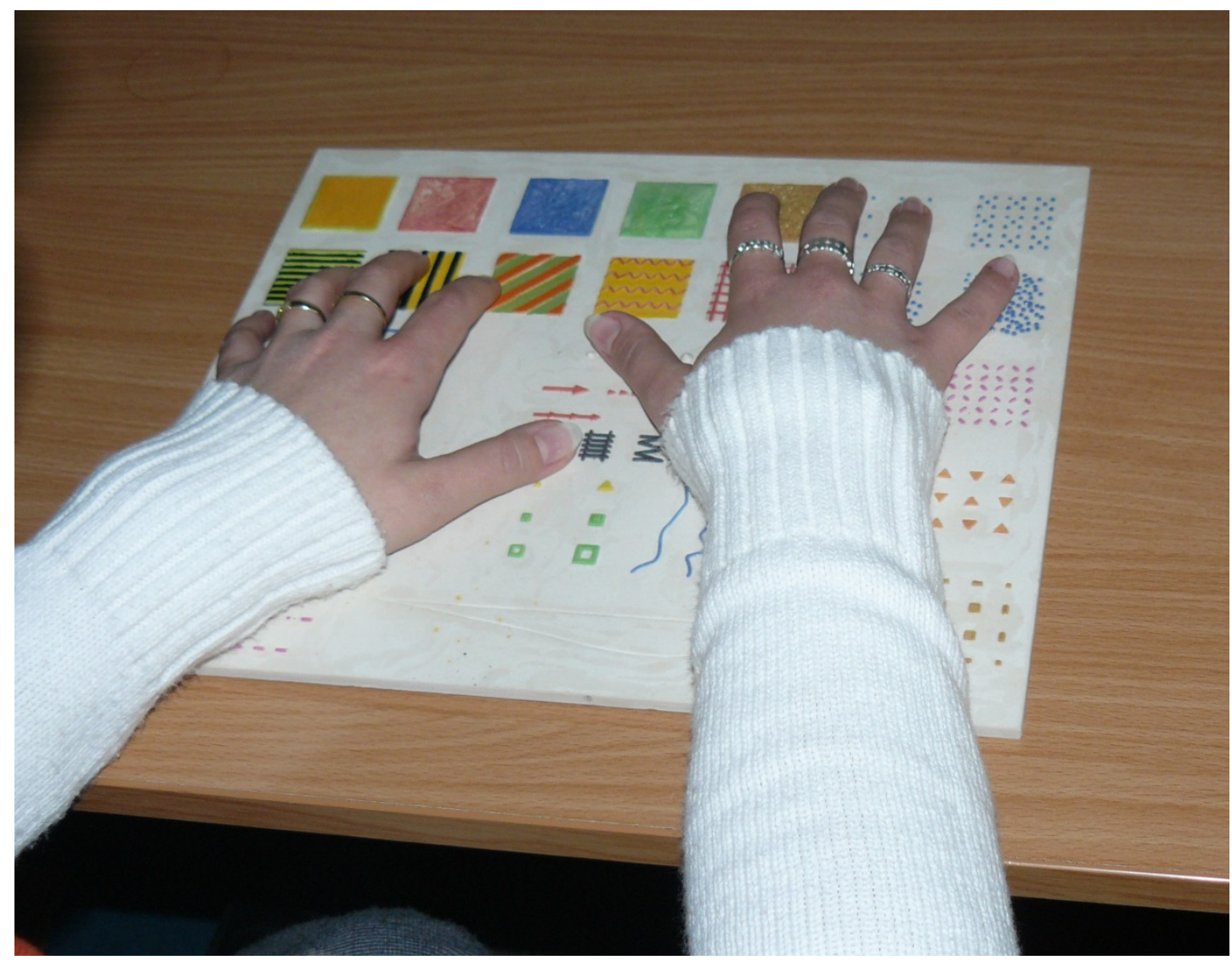

Figure 2 Testing board by the blind

In the above stated organizations, $80 \%$ of blind persons and $20 \%$ of persons with a severe visual debility from the selected number of respondents participated in the proposed testing, where a predominant group $(75 \%)$ of respondents were recruited from pupils and students of primary and secondary schools. The prevalence of tested individuals within school establishments was, according to our opinion, impacted by:

1) unsubstantiated prejudice of adults, concerning utilisation of such modern tactile maps in practical life,

2) awareness of school principals about the benefits of such modern type tactile maps within the teaching process.

For the purpose of testing, the authors have divided the sample card into several areas:

- line Aa, focused on roughness of material for persons with visual impairment on the level of blindness,

- line $\mathrm{Ab}$, focused on distinguishing colour intensity of samples and comparing colour spectrum of similar shade samples for persons with severe visual debility,

- line $\mathrm{Ba}$, differentiating in a structure of crosshatching in individual samples (blind persons), 
- line $\mathrm{Bb}$, differentiating of a colour contrast in crosshatched samples (persons with visual debility),

- column Ca and Da, focused on different structures of individual sectors with a different type of structural image, e.g. small and large triangles, intensity of dots, circles, etc. (blind persons),

- column $\mathrm{Cb}$ and $\mathrm{Db}$, together with $\mathrm{Ab}$, different intensity of shades in used colours (persons with visual debility),

- column E, which was focused on perception and differentiating of variations in embossed lines - simple, double, dot-and-dash, dotted, dashed and negative embossed lines,

- centre of the sample card $\mathrm{F}$ is focused on differentiating fine nuances between the embossed appearance of individual fine segments, e.g. arrows, traces/tracks, points (blind persons), this part was modified for persons with visual debility into appearance, which is visually distinguishable.

The following, and often surprising, findings result from the acquired data and conducted analysis:

- Aa - structure of this line of samples does not require changing (to the most segment 2 and 3 could be better differentiated),

- $\mathrm{Ab}, \mathrm{Cb}$ and $\mathrm{Db}$ - there is a need for slight increase in colour intensity of some samples (especially brown, ochre and orange), on the contrary blue, green and pink colours were completely satisfactory,

- $\mathrm{Ba}$ and $\mathrm{Bb}$ - the contrasts perceived through touch as well as vision are completely satisfactory,

- $\mathrm{Ca}$ and $\mathrm{Da}$ - some samples must be changed or their distinctiveness significantly increased,

- E - the negative embossment is not palpable, it must be more defined; double lines are distinguishable from simple lines; occasional difficulties when differentiating variations between dot-and-dash and dashed line,

- F - the legend of traces/tracks was satisfactory for all respondents, as well as a simple arrow, on the other hand a legend formed by very fine points was unsatisfactory - it was often confused.

Conclusions were drawn on the basis of the above stated test results, pursuant to which the current samples are being amended, and they will form the base for further material processing of modern type tactile maps within the project.

\section{Results and their practical utilisation}

The research outputs are new knowledge on theory of production and conceptual approaches of tactile maps and compiling methodology for tactile map symbology and creating font set of tactile symbols for selected GIS software (Nolan \& Morris, 1971). Guidelines for new type tactile maps design are completing including catalogue of geovisualization methods for tactile maps. The authors are currently applying examples of new type tactile maps to test possibility of sense of touch development in order to improve understanding 
spatial relationships, spatial orientation and movement of the blind based on higher awareness about space. The results are useful by all institutions (not only related to the blind) within public administration for decision making in the whole society and by all organisations dealing with spatial information (Perkins \& Gardiner, 1997).

The importance of the research for practice can be seen in using above mentioned results. In general research level the research brings methodological solution for geospace visualization at modern type tactile maps, methodology for the best interpretation method choosing of tactile map geodatabase and guidelines for their correct implementation (Greenspan \& Bolanowski, 1996). The methodology involves also specifics of automated production of three modern type tactile maps within GIS software (the most popular in the Czech Republic). The applicants assume that final tactile map examples and final book with all achieved results will be efficient tool for schools for blind children and many organisations which need to integrate the blind into various activities (employers, shopping centres, transport companies, subjects of emergency management etc.).

Further important research result will be reviewing and assessment of present-day Czech and foreign trends in using tools for geospace perception by the blind and users' requirements analysis on present tactile maps (type A, B, C) that will provide methodological background for many further research of similar specialisation.

Exploitation of the new type tactile maps is very large - including using within school education, applying by officers of regional centres for the blinds, local governments and development agencies (Siekierska\& Labelle, 2001). Produced tactile maps in three new types will serve for development of geospace perception and orientation of the blind - both children and adults (Brus, Voženílek \& Popelka, 2013). The maps will assist to remove fear of space and recognising unknown places.

\section{Acknowledgment}

The authors gratefully acknowledge the support by the Operational Program Education for Competitiveness - European Social Fund (project CZ.1.07/2.3.00/20.0170 of the Ministry of Education, Youth and Sports of the Czech Republic).

\section{References}

1. Brus, J., Voženílek, V., Popelka, S. (2013). An assessment of quantitative uncertainty visualization methods for interpolated meteorological data. Lecture Notes in Computer Science, Vol. 7974 LNCS, Issue PART 4, 166-178.

2. Brychtová, A., Popelka, S., Voženílek, V. (2012). The Analysis of Eye Movement as a Tool for Evaluation of Maps and Graphical Outputs from GIS. Proceedings of 19th International Conference on Geography and Geoinformatics: Challenge for Practise and Education, Brno, 08-09, 2011, 154-162. 
3. Burian, J., Brus, J., Voženílek, V. (2013). Development of Olomouc city in 1930-2009: based on analysis of functional areas. Journal of Maps, 9(1), 64-67.

4. Dvorský, J., Snášel, V., Voženílek, V. (2009). Map Similarity Testing Using Matrix Decomposition. 2009 International Conference on Intelligent Networking and Collaborative Systems (INCOS 2009), 290-294.

5. Dvorský, J., Snášel, V., Voženílek, V. (2010). On maps comparison methods. 2010 International Conference on Computer Information Systems and Industrial Management Applications, CISIM 2010, art. no. 5643513, 557-562.

6. Edman, P.K. (1992). Tactile Graphics. New York: American Foundation for the Blind.

7. Gilbert C.P. (1988).Touchdown Sheepville. Royal Blind Society of New South Wales.

8. Greenspan, J.D., Bolanowski, S.J. (1996). The psychophysics of tactile perception and its peripheral physiological basis. San Diego, Academic Press, 25-104.

9. Hirn, H. (2005): Tactile maps for preschool children: the curriculum. Proceedings of XXII International Cartographic ConferenceACoruña 2005 proceedings, CD.

10. Horák, Z., Kudělka, M., Snášel, V., Voženílek, V. (2011). Orthophoto map feature extraction based on neural networks. CEUR Workshop Proceedings, Vol. 706, 216-225.

11. Jesenský, J. (1970).Poznáva cívýznamtyflo grafiky. Praha, SPN, 1970.

12. Lamotte, R.H., Whitehouse, J. (1986). Tactile detection of a dot on a smooth surface: peripheral neural events. Journal of Neurophysiology, 56 (4), 1109-1128.

13. Lederman, S.J. (1974).Tactile roughness of grooved surfaces: the touching process and effects of macro- and micro-surface structure. Perception and Psychophysics, 16(2), 385395.

14. Nolan, C.Y., Morris, J.E. (1971).Improvement of Tactual Symbols for Blind Children. Final Report, Washington, DC, Department of Health, Education and Welfare.

15. Perkins, C., Gardiner, A. (1997). "What I really, really want": how visually impaired people can improve tactile map design. Proceedings of 18th ICA/ACI International Cartographic Conference: Stockholm, Sweden, 23-27 June 1997, Ottoson, L (Ed.). Stockholm: Swedish Cartographic Society, 4, 1159-1166.

16. Popelka, S., Brychtová, A., Voženílek, V. (2012). Eye-tracking a jeho využití pri hodnocení map | [Eye-tracking and its use forassessmentofmaps]. Geografickýčasopis, 64(1), 71-87.

17. Popelka, S., Voženílek, V. (2012). Specifying of Requirements for Spatio-Temporal Data in Map by Eye-Tracking and Space-Time-Cube. International Conference on Graphic and Image Processing (ICGIP 2012), Proceedings of SPIE, Vol. 8768, Article Number: $87684 \mathrm{~N}$.

18. Rowell, J., Ungar, S. (2005). Feeling our way: Tactile map user requirements - a survey. Proceedings of XXII International Cartographic Conference ACoruña 2005 proceedings, CD.

19. Siekierska, E., Labelle, R. (2001). Tactile mapping project at Canadian Federal Mapping Agency - Mapping Services Branch. Proceedings of the 20th International Cartographic Conference, ICC 2001 Beijing China, August 6-10, 2001. Mapping the 21st Century, Scientific and Technical Program Committee LOC for ICC 2001 Beijing China (Eds.). Beijing: Chinese Society of Geodesy Photogrammetry and Cartography, 5, 2932-2942.

20. Svobodová, J., Voženílek, V. (2010).ReliefforModelsof Natural Phenomena. In: Anděl, J., Bičík, I., Dostál, P.,Shasneshin, S. (eds.): Landscape Modelling: GeographicalSpace, Transformation and FutureScenarios. Dordrecht, Springer, 183-196.

21. Theissen, N. (2000). Computer-aided Tactual Graphics (Getting Started...). Enfield, Royal Blind Society.

22. Tuček, P., Pászto, V., Voženílek, V. (2009). Regular use of entropy for studying dissimilar geographical phenomena. Geografie, 114(2), 117-129. 
23. Ungar, S., Jehoel, S., Mccallum, D., Rowell, J. (2005). "Tactualization" of spatial information: towards a perceptual-cognitive approach to tactile map design. Proceedings of XXII International Cartographic Conference ACoruña 2005 proceedings, CD.

24. Vondráková, A., Vávra, A., Voženílek, V. (2013). Climatic Regions of the Czech Republic. Journal of Maps, 9(3), 425-430.

25. Voženílek, V. (2002). Geoinformatic literacy: Indispensability or nonsense? [Geoinformatickágramotnost: nezbytnostnebonesmysl?] Geografie, 107(4), 371-382.

26. Voženílek, V. (2002). Terrain Sensitivity in Environmental Models. Geografie, 107(2), 111-120.

27. Voženílek, V. (2009). Artificial intelligence and GIS: mutual meeting and passing. 2009 International Conference on Intelligent Networking and Collaborative Systems (INCOS 2009), 279-284.

28. Voženílek, V., Kudělka, M., Horák, Z., Snášel, V. (2012). Orthophoto Feature Extraction and Clustering. Neural Network World, 22(2), 103-121.

29. Wiedel, J.W., Groves, P.A. (1969). Tactual Mapping: Design, Reproduction, Reading and Interpretation. Washington, DC, Department of Health, Education and Welfare.

Prof. Dr. Vít Voženílek

Dr. Alena Vondráková
Department of Geoinformatics, Palacky University

Olomouc 17. listopadu 50

77146 Olomouc, Czech Republic

e-mail: vit.vozenilek@upol.cz

tel: +420585634513

Department of Geoinformatics, Palacky University

Olomouc 17. listopadu 50

77146 Olomouc, Czech Republic

e-mail:alena.vondrakova@upol.cz

tel: +420585634517 